\title{
Foliar Fertilizer Based on Calcined Bones, Boron and Molybdenum-A Study on the Development and Potential Effects on Maize Grain Production
}

\author{
Maciej Balawejder 1,*, Natalia Matłok ${ }^{2}$, Józef Gorzelany ${ }^{2}$, Marcin Pieniążek ${ }^{3}$, Piotr Antos ${ }^{4}$, \\ Grzegorz Witek ${ }^{5}$ and Małgorzata Szostek ${ }^{3}$ \\ 1 Department of Chemistry and Food Toxicology, University of Rzeszow, 35-601 Rzeszów, Poland \\ 2 Department of Food and Agriculture Production Engineering, University of Rzeszow, \\ 35-601 Rzeszów, Poland; natalia.matlok@onet.pl (N.M.); gorzelan@ur.edu.pl (J.G.) \\ 3 Department of Soil Sciences, Environmental Chemistry and Hydrology, University of Rzeszow, \\ 35-601 Rzeszów, Poland; mpieniadz@op.pl (M.P.); mszostek@univ.rzeszow.pl (M.S.) \\ 4 Department of Computer Engineering in Management, Rzeszow University of Technology, \\ 35-959 Rzeszów, Poland; piotr_antos@o2.pl \\ 5 Dr Green Sp. Z.o.o., 32-500 Chrzanów, Poland; g.witek@dr-green.pl \\ * Correspondence: maciejb@ur.edu.pl
}

Received: 6 August 2019; Accepted: 20 September 2019; Published: 25 September 2019

check for updates

\begin{abstract}
Phosphorus is a biogenic element with a high importance within the food chain. Regrettably, there are limited amounts of phosphorus within minerals naturally occurring in the environment. Its scarcity leads to a necessity of closed loop economy, where this element could be obtained by the processing of various waste materials. Modern agriculture needs to provide sufficient amounts of phosphorus to plant organisms encountering problems with the bioavailability of nutrition. In this research, a post-processed animal waste material (calcined bone) was utilized to reclaim phosphorus and reintroduce it into the environment in a form of foliar fertilizer. The calcined bones were subjected to chemical transformation with nitric acid solution. The solubilization of bones was followed by laboratory-scale pot experiments, in which the fertilizer was used for the cultivation of maize plants. In the field experiments, the fertilizer was additionally fortified with boron and molybdenum elements. It was observed that the utilization of the fertilizer had a positive impact on maize plants, i.e., improvement in the biomass production of aboveground and underground parts of the plants. The amount of chlorophyll increased in comparison to control plants. Maize grain production was increased by approximately $600 \mathrm{~kg} \mathrm{ha}^{-1}$ ).
\end{abstract}

Keywords: closed loop economy; calcined bones; phosphorus; foliar fertilizer; maize

\section{Introduction}

Phosphorus is a biogenic element that is crucial for sustaining life in various forms, whether microorganisms, plants or animals [1-3]. Therefore, compounds with phosphorus in their structure have great importance within the food chain. Historically, guano was used as the source of phosphorus for the growth and development of plant organisms in areas of cultivation. In the last century, minerals containing phosphorus became a dominant source of this element. Modern agriculture is based on artificial fertilizers that include elements such as N, P, K and other microelements and macroelements [1]. The need to provide sufficient amounts of phosphorus to plant organisms encounters two major obstacles. On the one hand, there is a scarcity of this element within natural minerals, and, on the other hand, minerals that contain phosphorus in various forms may be contaminated with a number of heavy metals. Moreover, the occurrence of phosphorus in various minerals does not always result in 
its bioavailability to various plants. It is reported that 67 billion $t$ of phosphate minerals are present in the world, with the concentration of phosphorus (expressed as $\mathrm{P}_{2} \mathrm{O}_{5}$ ) within the range of $28 \%$ to $39 \%$ [2]. Unfortunately, it is expected that, in the next century, over a half of these deposits will be used up. Another challenge is the uneven distribution of this element within the world, thus some countries are left without any sort of natural supply of this resource. Most reserves of this resource lay in the earth crust of African countries, such as Morocco, Algeria, South Africa, some in the Middle East (Syria) and others in China. Together, those countries control almost $90 \%$ of the total supply of this resource [3]. Another obstacle for providing plants with the sufficient amount of phosphorus is the necessity of the processing of raw minerals in order to prepare a fertilizer that would include phosphorus elements in a bioavailable form. Due to the scarcity of this resource and a high degree of loses during agricultural runoff, erosion and animal waste, there is a high emphasis put on the recovery of this element from various processing chains [4]. The solution of this problem might be a closed loop economy with maximal recovery of this valuable element $[2,5]$. The recovery of phosphorus from different waste, such as manure, wastewater, sewage sludge, digestate from biogas production or ashes from sewage sludge incineration, and reintroduction as a fertilizer is considered a good approach [6,7]. Ehmann et al., 2017, developed a method to reclaim phosphorus and other nutrients from manure. The generated biocarbons that were rich with phosphorus-containing compounds were tested in pot experiments aimed at the comparison of their efficiency with conventional phosphorus fertilizers. It was concluded that the biocarbons can improve the impact of the phosphorus fertilizers [7]. An attractive alternative source of phosphorus may by the sewage sludge after a treatment. Sewage sludge that was subjected to fermentation in various conditions was tested in field conditions utilizing various doses as a fertilizer. The efficiency of the fertilization process was investigated using a number of analytical techniques including 31P-NMR. It was concluded that fertilization with sewage sludge can be beneficial in the initial vegetation period. Furthermore, it was indicated there was a great diversity between the efficiency of the utilized sewage sludge types [8].

One of the possible sources of phosphorus is the utilization of animal waste and, in particular, animal bones. Bones consist of $70 \%$ of inorganic minerals (apatites) and organic compounds [1,9]. Already in 1770, when it was discovered that phosphorus is one of the minerals present in bones, a number of attempts were made to recover it. For many years, bones were substrates from which phosphorus and phosphoric acid were produced. In comparison to minerals that may be obtained via mining, animal bones contain a significantly lower amount of contaminants such as heavy metal ions [10].

Before the numerous cases of Bovine spongiform encephalopathy (BSE) disease, caused by the consumption of contaminated bone meal, the meat and bone meal (MBM) could be utilized for the recovery of some amounts of phosphorus [11]. Nowadays, other methods for the recovery of this element are needed. One such method is the utilization of microbes to solubilize phosphorus-rich minerals $[5,6,10]$. Demirbas et al. developed a method for the recovery of phosphorus from calcined bones using hydrochloric acid solutions with various concentrations. The optimization of the solubilization process was carried out using the Taguchi fractional design method. The efficiency of the recovery process was established at $67.2 \% \mathrm{P}_{2} \mathrm{O}_{5}$. Although the process efficiency is satisfactory, the obtained fraction is not suitable for direct fertilization due to the high content of $\mathrm{Cl}^{-}$ions, which cause soil salinity [12].

Phosphate deposits may originate from teeth, bones and excrements of marine organisms or pre-historic life. Those deposits may be reclaimed into the phosphorus cycle within the food chain. Microorganisms can be responsible for the breakdown of phosphates using enzymes such as phosphatase, phytase, and nucleotidase [10]. The solubilization of phosphates may also occur through the generation of inorganic and organic acids, which eventually leads to the dissolution of solid phosphates [13-15]. This indicates that the utilization of acids to solubilize phosphorus present in minerals, which are a part of bones, is a viable option to reclaim this element. However, using acids 
such as sulfuric acid leads to the formation of the so called phosphogypsum, which results in the loss of bioavailable phosphorus.

The aim of this work was to develop an effective method for the solubilization of mineral compounds from calcined bones and to use it to prepare foliar fertilizer. The fertilizer was tested in both pot experiments and field conditions.

\section{Materials and Methods}

\subsection{Materials}

The bone material originated from a cattle slaughterhouse and was thermally processed at temperatures in the range of $850-950^{\circ} \mathrm{C}$ and grounded to achieve particles no larger than $2 \mathrm{~mm}$.

\subsection{The Process for the Solubilization of Minerals from Calcined Bones}

The raw bone material obtained after calcination and grounding was weighed and placed into conical flasks and then nitric acid solution was added. The reaction mixtures were prepared by mixing components such as $42 \mathrm{~g}$ of $65 \%$ nitric acid (V) that was bought from Chempur (Piekary Ślaskie, Poland) with $120 \mathrm{~g}$ of deionized water and $25 \mathrm{~g}$ of calcined bones. Next, the slurries were stirred by a magnetic stirrer at $500 \mathrm{rpm}$. Solubilization was carried out for $1 \mathrm{~h}$ at $20^{\circ} \mathrm{C}$. After that, the contents of the flasks were transferred to falcons and centrifuged for $5 \mathrm{~min}$ at $2500 \mathrm{rpm}$. The supernatant obtained was decanted and the precipitate was rinsed with distilled water and centrifuged again under identical conditions. The combined supernatant was transferred into round-bottom flasks, and then most of the solvent was removed using a Heidolph Hei Vap Adventage (Schwabach, Germany) rotary evaporator under reduced pressure $(0.01 \mathrm{MPa})$. The residue, in a form of a paste, was transferred into a pre-tared petri dish and dried to a constant weight. Next, the fractions obtained after crushing in a porcelain mortar were kept for further analysis as well as, after dilution, use as a foliar fertilizer (Table 1.).

Table 1. Determined mineral composition of the bone waste material.

\begin{tabular}{|c|c|c|c|c|c|c|c|c|c|}
\hline $\mathrm{Na}$ & $\mathbf{K}$ & Mg & $\mathrm{Ca}$ & $\mathbf{P}$ & $\mathbf{N}$ & $\mathrm{Fe}$ & Mn & $\mathrm{Zn}$ & $\mathrm{Cu}$ \\
\hline \multicolumn{5}{|c|}{$\mathrm{g} \mathrm{kg}^{-1}$} & \multicolumn{5}{|c|}{$\mathrm{mg} \mathrm{kg}^{-1}$} \\
\hline $\begin{array}{c}4.74 \pm \\
0.43\end{array}$ & $\begin{array}{c}37.48 \pm \\
3.50\end{array}$ & $\begin{array}{c}16.77 \pm \\
1.25\end{array}$ & $\begin{array}{c}492.46 \pm \\
9.51\end{array}$ & $\begin{array}{c}161.13 \pm \\
0.7\end{array}$ & $\begin{array}{c}0.06 \\
\pm 0.01\end{array}$ & $\begin{array}{c}21.03 \pm \\
0.80\end{array}$ & $\begin{array}{c}80.76 \pm \\
2.22\end{array}$ & $\begin{array}{c}10.40 \pm \\
0.04\end{array}$ & $\begin{array}{c}40.44 \pm \\
0.97\end{array}$ \\
\hline
\end{tabular}

The process conditions were scaled up to an industrial scale by increasing the apparatus dimensions. For the solubilization procedure, a reactor equipped with a propeller stirrer with a volume of $1 \mathrm{~m}^{3}$ was utilized. A total of $480 \mathrm{~kg}$ of water was placed into the reactor and, next, $100 \mathrm{~kg}$ of grounded bones was introduced. Then, $168 \mathrm{~kg}$ of $65 \%$ nitric acid was introduced into the reactor. The acid was dosed into the reactor for one hour. The obtained solution was than filtrated with a filter cloth with a pore size of $25 \mu \mathrm{m}$. The recovery of the mineral compounds present in the solution was at the level of $95 \%$. In the next step, the solution was introduced into a fluidized bed granulator (Glatt $\mathrm{GmbH}$, Binzen, Germany) that was filled with boric acid, which had a particle size of $0.2-0.5 \mathrm{~mm}$, and ammonium heptamolybdate. The granulation procedure was conducted by the spraying of the solution on the surface of boric acid coupled with a drying process at a temperature of $45^{\circ} \mathrm{C}$.

\subsection{Description of the Pot Experiments}

The one-way pot experiment was carried out in the vegetation hall. The external conditions, such as temperature and humidity, were controlled. For lighting during cultivation, an LED based technology was used on the plants. The variable factor investigated was the effect of the developed foliar fertilizer on both the growth and the development of the maize variety Farm Gigant (thousand kernel weight $=264 \mathrm{~g}$ ). In the pot experiments, there were control plants (without foliar fertilizing) 
and three groups of plants, which were fertilized with different doses of the product solution-11.8 $\mathrm{mg}$ $\operatorname{pot}^{-1}\left(1.0 \mathrm{~kg} \mathrm{ha}^{-1}\right), 23.6 \mathrm{mg} \mathrm{pot}^{-1}\left(2.0 \mathrm{~kg} \mathrm{ha}^{-1}\right)$ and $35.4 \mathrm{mg} \mathrm{pot}^{-1}\left(3.0 \mathrm{~kg} \mathrm{ha}^{-1}\right)$. The experiment was carried out in 10 replications for each variant in a completely random arrangement (Table 2).

The experiments were carried out in the production pots, wherein $3 \mathrm{~kg}$ of soil with a granulometric composition loamy sand of lightly acidic $\mathrm{pH}\left(\mathrm{pH}: \mathrm{KCl}, 6.35 ; \mathrm{H}_{2} \mathrm{O}, 6.52\right)$ was placed. During the experiment, a constant humidity of $50 \%$ of the maximum water-holding capacity (WHC) was sustained for the soil in the vases. The application of the test solutions of fertilizer doses was conducted manually by diluting the developed fertilizer in water; the fertilizer volume used was $200 \mathrm{dm}^{3} \mathrm{ha}^{-1}$. The application of the foliar fertilizer was conducted at an ambient temperature of $22^{\circ} \mathrm{C}$ during the 5 th leaves phase (BBCH 15) [16]. Then, 14 days after the second application of the fertilizer, a measurement of the relative amount of chlorophyll within the flag leaf was conducted using a device, SPAD 502 (Konica-Minolta INC, Osaka, Japan) [17]. Next, the plants from each vase were isolated and cleaned up from the soil particles. The maize plantlets were divided into aboveground and underground parts, and both were subjected to further analyses.

\subsection{Description of the Field Experiments}

For field experiments, a foliar fertilizer was used; the base of the product was an isolate (Table 3) with compounds of boron ( $395 \mathrm{~g} \mathrm{~kg}^{-1}$ Boric acid, Parnter Chem, Lublin, Poland ) and molybdenum (3.5 g kg-1 Ammonium heptamolybdate $\left.\left(\mathrm{NH}_{4}\right)_{6} \mathrm{Mo}^{-1} \mathrm{O}_{24}\right)$, Centrum Metal Odczynniki Chemiczne Midas-Investment, Falenty, Poland) (Table 4). The presence of boron is responsible for correct pollination and filling of the cobs with grain. Also, the presence of B in maize strengthens the stiffness of the stems, which reduces lodging and protects plants from pests. Insufficient molybdenum content within plants causes the inhibition of chlorophyll synthesis, an increase in the content of inorganic $\mathrm{P}$, which should be incorporated into organic structures under normal conditions, and a decrease in pollen production and lifetime. For the spraying procedure, Matrot maestria, Tecnoma laser, Allaeys and Rau Vicon kverneland sprayers were utilized. The sowing density was 70,000 seeds ha $^{-1}$, and the weeds were controlled using standard pest control procedures for maize cultivation; the maize variety Farm Gigant was used. The verification of the tested foliar fertilizer was carried out in field conditions, in field experiments in 2018, in 8 locations in Poland. The area of each location was 5 ha. The experiment was carried out in parallel in different regions (I, II and IV), more or less favorably for the cultivation of maize (Figure 1, Table 2).

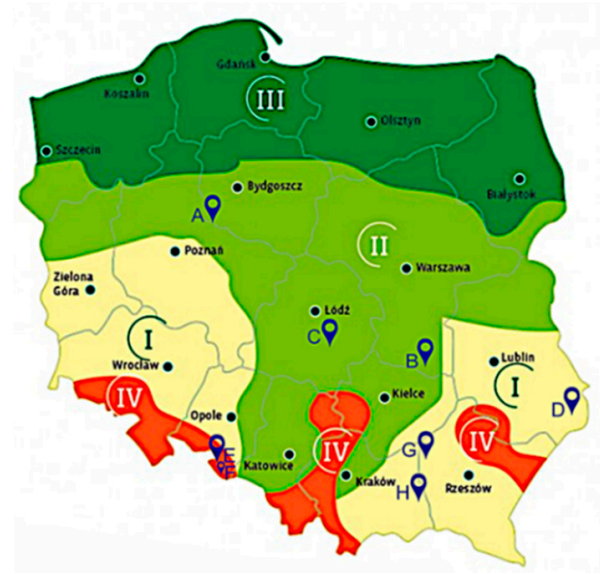

Figure 1. The division of Poland into climatic regions for the cultivation of maize (adapted from [18]). 
Table 2. Characteristics of the location, weather and soil conditions during field experiments.

\begin{tabular}{|c|c|c|c|c|c|c|c|c|c|c|}
\hline \multirow{3}{*}{\multicolumn{2}{|c|}{ Location }} & \multirow{3}{*}{$\begin{array}{l}\text { Climatic Region of } \\
\text { Poland } \\
\text { for Maize Cultivation } \\
\text { (Figure 1) }\end{array}$} & \multicolumn{2}{|c|}{$\begin{array}{c}\text { Meteorological Conditions in the Vegetative } \\
\text { Period } 2018 \\
\text { [19] }\end{array}$} & \multicolumn{5}{|c|}{ Soil Conditions } & \multirow{3}{*}{ Fore Crop } \\
\hline & & & Sum of Rainfall & Average Temp. & $\begin{array}{c}\text { Granulometric Composition } \\
\text { (USDA) }\end{array}$ & \multirow{2}{*}{$\begin{array}{l}\mathrm{pH} \\
\mathrm{KCl} \\
\left.\mathrm{H}_{2} \mathrm{O}\right)\end{array}$} & Mg & $\mathrm{K}$ & $\mathbf{P}$ & \\
\hline & & & $\mathrm{mm}$ & ${ }^{\circ} \mathrm{C}$ & & & \multicolumn{3}{|c|}{$\mathrm{mg} \mathrm{kg}^{-1}$} & \\
\hline A & $\begin{array}{l}52^{\circ} 36^{\prime} 33.8^{\prime \prime} \mathrm{N} \\
17^{\circ} 24^{\prime} 06.2^{\prime \prime} \mathrm{E}\end{array}$ & II (FAO 230-260) & 200 & 18.2 & sand & $6.80,7.10$ & 170 & 196 & 45.3 & colza \\
\hline B & $\begin{array}{l}50^{\circ} 53^{\prime} 09.4^{\prime \prime} \mathrm{N} \\
21^{\circ} 29^{\prime} 35.6^{\prime \prime} \mathrm{E}\end{array}$ & II (FAO 230-260) & 275 & 18.4 & sandy loam & $5.78,5.96$ & 68 & 79 & 10.9 & carrot \\
\hline $\mathrm{C}$ & $\begin{array}{l}51^{\circ} 28^{\prime} 32.5^{\prime \prime} \mathrm{N} \\
19^{\circ} 49^{\prime} 48.0^{\prime \prime} \mathrm{E}\end{array}$ & II (FAO 230-260) & 323 & 17.2 & loamy sand & $7.18,7.42$ & 55 & 118 & 92.0 & winter wheat \\
\hline $\mathrm{D}$ & $\begin{array}{l}50^{\circ} 27^{\prime} 25.5^{\prime \prime} \mathrm{N} \\
23^{\circ} 46^{\prime} 33.4^{\prime \prime} \mathrm{E}\end{array}$ & I (FAO do 300) & 298 & 17.4 & sandy loam & $6.45,6.80$ & 93 & 171 & 20.5 & $\begin{array}{l}\text { winter wheat/straw } \\
\text { ploughed }\end{array}$ \\
\hline E & $\begin{array}{l}50^{\circ} 05^{\prime} 03.6^{\prime \prime} \mathrm{N} \\
17^{\circ} 49^{\prime} 43.3^{\prime \prime} \mathrm{E}\end{array}$ & IV (FAO do 200) & 312 & 18.2 & sandy loam & $6.69,7.04$ & 118 & 273 & 42.7 & $\begin{array}{l}\text { winter wheat/straw } \\
\text { ploughed }\end{array}$ \\
\hline $\mathrm{F}$ & $\begin{array}{l}49^{\circ} 59^{\prime} 32.6^{\prime \prime} \mathrm{N} \\
18^{\circ} 15^{\prime} 26.8^{\prime \prime} \mathrm{E}\end{array}$ & IV (FAO do 200) & 352 & 17.6 & loamy sand & $6.94,7.25$ & 90 & 323 & 46.7 & colza \\
\hline G & $\begin{array}{l}50^{\circ} 03^{\prime} 55.6^{\prime \prime} \mathrm{N} \\
21^{\circ} 03^{\prime} 02.0^{\prime \prime} \mathrm{E}\end{array}$ & I (FAO do 300) & 405 & 17.8 & loamy sand & $5.50,5.91$ & 218 & 249 & 15.3 & winter wheat \\
\hline $\mathrm{H}$ & $\begin{array}{l}50^{\circ} 20^{\prime} 14.9^{\prime \prime} \mathrm{N} \\
21^{\circ} 21^{\prime} 24.9^{\prime \prime} \mathrm{E}\end{array}$ & I (FAO do 300) & 261 & 17.7 & loamy sand & $5.42,5.80$ & 266 & 226 & 40.5 & maize for grain \\
\hline
\end{tabular}


Table 3. Concentration of macro- and microelements in the soluble fraction of calcined bones obtained after solubilization with nitric acid solution.

\begin{tabular}{|c|c|c|c|}
\hline $\begin{array}{l}\text { Content of the Acquired } \\
\text { Soluble Fraction }\end{array}$ & $\%$ & \multicolumn{2}{|c|}{$75.62 \pm 0.38$} \\
\hline $\mathrm{Na}$ & $\mathbf{K}$ & $\mathrm{Mg}$ & $\mathrm{Ca}$ \\
\hline \multicolumn{4}{|c|}{$\mathrm{g} \mathrm{kg}^{-1}$} \\
\hline $6.50 \pm 0.59$ & $2.01 \pm 0.05$ & $8.45 \pm 1.55$ & $138.98 \pm 7.30$ \\
\hline $\mathrm{N}$ & $\mathrm{Cl}$ & $\mathrm{P}$ & $S$ \\
\hline \multicolumn{4}{|c|}{$\mathrm{g} \mathrm{kg}^{-1}$} \\
\hline $107.48 \pm 3.25$ & $0.45 \pm 0.03$ & 111.22 & $1.25 \pm 0.02$ \\
\hline $\mathrm{Fe}$ & Mn & $\mathrm{Zn}$ & $\mathrm{Cu}$ \\
\hline \multicolumn{4}{|c|}{$\mathrm{mg} \mathrm{kg}^{-1}$} \\
\hline $12.60 \pm 0.22$ & $0.62 \pm 0.13$ & $9.59 \pm 0.24$ & $1.75 \pm 0.13$ \\
\hline
\end{tabular}

Table 4. Mineral composition of the isolate with boron and molybdenum compounds.

\begin{tabular}{|c|c|c|c|c|c|c|c|c|c|c|}
\hline \multicolumn{11}{|c|}{ Mineral Composition of Foliar Fertilizer } \\
\hline$P\left(g_{k g}^{-1}\right)$ & $N\left(\mathrm{~g} \mathrm{~kg}^{-1}\right)$ & $\begin{array}{c}\mathrm{Na} \\
\left(\mathrm{g} \mathrm{kg}^{-1}\right)\end{array}$ & $K\left(\mathrm{~g} \mathrm{~kg}^{-1}\right)$ & $\underset{\left(\mathrm{g} \mathrm{kg}^{-1}\right)}{\mathrm{Mg}}$ & $\begin{array}{c}\mathrm{Ca} \\
\left(\mathrm{g} \mathrm{kg}^{-1}\right)\end{array}$ & $B\left(\mathrm{~g} \mathrm{~kg}^{-1}\right)$ & $\begin{array}{c}\text { Mo } \\
\left(\mathrm{g} \mathrm{kg}^{-1}\right)\end{array}$ & $\begin{array}{c}\mathrm{Fe} \\
\left(\mathrm{mg} \mathrm{kg}^{-1}\right)\end{array}$ & $\begin{array}{c}\mathrm{Zn} \\
\left(\mathrm{mg} \mathrm{kg}^{-1}\right)\end{array}$ & $\begin{array}{c}\mathrm{Cu} \\
\left(\mathrm{mg} \mathrm{kg}^{-1}\right)\end{array}$ \\
\hline 48.8 & 12.5 & 4.2 & 1.2 & 4.4 & 80.3 & 70 & 2 & 10 & 8 & 1.5 \\
\hline
\end{tabular}

The most favorable climatic conditions for growing maize occur in region I, which covers the southwestern and southeastern parts of Poland. This region is characterized by the longest vegetative period, favorable rainfall distribution and high average air temperature. In region II, covering the central part of Poland, in warm summer and favorable distribution of rainfall, a high yield of maize grain is also obtained. Unfavorable conditions that occur in the foothill regions (region IV) limit the cultivation of maize in these areas. The field experiment scheme was designed to replace the 3 year period scheme, since the tested fertilizer was tested in parallel in several locations, characterized not only by different climatic but also soil conditions (Table 2).

The applied fertilizer was tested in May. The average sum of rainfall ranged from $200 \mathrm{~mm}$ in location $\mathrm{A}$ to $405 \mathrm{~mm}$ in location $\mathrm{G}$, and the average air temperature during the experiment ranged from $17.2{ }^{\circ} \mathrm{C}$ (location C) to $18.4{ }^{\circ} \mathrm{C}$ (location B). The granulometric composition of soils on which the experiments were carried out corresponded to sand (location $A)$, sandy loam (B, D, E) and loamy sand (C, F, G, H) (Table 1). The $\mathrm{pH}$ values of these soils were moderately acidic (5.80) to slightly alkaline (7.42). Soil samples of soils on which experiments were carried out were also characterized by diversified abundance in digestible forms of macroelements. The content of available magnesium ranged from 55 (location $\mathrm{C}$ ) to $266 \mathrm{mg} \mathrm{kg}^{-1}$ (location $\mathrm{H}$ ), digestible potassium from 79 (location $\mathrm{B}$ ) to $323 \mathrm{mg} \mathrm{kg}^{-1}$ (location F), and phosphorus from 10.9 (location B) to $92 \mathrm{mg} \mathrm{kg}^{-1}$ (location C).

In the field experiment, a dose of $3.0 \mathrm{~kg} \mathrm{ha}^{-1}$ of the fertilizer preselected in the pot experiment was tested in parallel to the control plant (no fertilization). The working fluid in the amount of $200 \mathrm{dm}^{3} \mathrm{ha}^{-1}$ was applied in the 6th leaf phase (BBCH 16). The size of the experimental fields was 5 ha. As in the case of the pot experiments, 14 days after the foliar fertilization treatment, the biometric features of 20 randomly selected plants from each experiment object were measured. The maize harvest was carried out on 5 to 20 November in all areas, and then the grain yield and its moisture were determined.

\subsection{Analysis of Raw Materials and Plants}

To dissolve mineral components, samples of calcined bone and plants were contacted with concentrated acids. Calcined bone was digested using $70 \% \mathrm{HClO}_{4}$ in mineralizator Tecator (FOSS, Hilleroed, Denmark) using the following temperature scheme: $165^{\circ} \mathrm{C}$ by $2 \mathrm{~h}, 200{ }^{\circ} \mathrm{C} 2.5 \mathrm{~h}^{-1}, 210^{\circ} \mathrm{C}$ 
$0.5 \mathrm{~h}^{-1}$, and $230^{\circ} \mathrm{C} \mathrm{h}^{-1}$. The plants were digested using acids mixture composed of concentrated acids $\left(\mathrm{HNO}_{3}: \mathrm{HClO}_{4}: \mathrm{H}_{2} \mathrm{SO}_{4}\right)$ in a ratio of 20:5:1 using mineralizator Tecator with the following temperature scheme: $70^{\circ} \mathrm{C}$ by $1.0 \mathrm{~h}, 105^{\circ} \mathrm{C}$ by $1.0 \mathrm{~h}, 120^{\circ} \mathrm{C}$ by $1.0 \mathrm{~h}, 160^{\circ} \mathrm{C}$ by $2.0 \mathrm{~h}, 167^{\circ} \mathrm{C}$ by $2.0 \mathrm{~h}$, and $200^{\circ} \mathrm{C}$ by $1.0 \mathrm{~h}$.

The samples of the product were analyzed using an AAS Hitachi Z-2000 (Hitachi, Tokyo, Japan) for the determination of $\mathrm{Fe}, \mathrm{Mn}, \mathrm{Zn}, \mathrm{Cu} \mathrm{Ca}, \mathrm{Mg}, \mathrm{K}$ and $\mathrm{Na}$. The content of phosphorus was determined in solution generated by digestion process, according to the vanadium-molybdenum method [20]. The concentration of phosphorus was determined using a colorimetric assay, based on the formation of colored complexes that form orthophosphate ions in the presence of vanadium and molybdenum ions. The measurements were performed using a spectrophotometer Shimadzu UV-2600 at a wavelength of $435 \mathrm{~nm}$.

Analysis of the ions was conducted using system DIONEX 5000+ HPIC (Thermo Fisher Scientific, Sunnyvale, USA). The prepared solutions of the foliar fertilizers were filtered through syringe filters. The parameters of anions analysis were as follows: the column Dionex AS9 HC $250 \times 4 \mathrm{~mm}$ and a protective column Dionex AG $50 \times 4 \mathrm{~mm}$, flow rate $1 \mathrm{~cm}^{3} \mathrm{~min}^{-1}$; column oven temperature- $30{ }^{\circ} \mathrm{C}$, suppressor ASRS $4 \mathrm{~mm}$, current $45 \mathrm{~mA}$. As the eluent, a $18 \mathrm{mM}$ solution of $\mathrm{Na}_{2} \mathrm{CO}_{3}$ was used. The injection volume was $25 \mu \mathrm{L}$. The concentration of cations was determined using Dionex CS $16250 \times$ $5 \mathrm{~mm}$ column and a Dionex CG16 $50 \times 5 \mathrm{~mm}$ protective column. The flow rate was $1.4 \mathrm{~cm}^{3} \mathrm{~min}^{-1}$; column oven temperature was $40^{\circ} \mathrm{C}$, suppressor CSRS $4 \mathrm{~mm}$, and current was $123 \mathrm{~mA}$. As the eluent, a $30 \mathrm{mM}$ solution of methanosulfonic acid was used. The injection volume was $5 \mu \mathrm{L}$. The temperature of the detector was $40^{\circ} \mathrm{C}$. The quantitative analysis was based on standard curves prepared by injecting a series of standards.

\subsection{Statistical Analysis}

The statistical analysis of the obtained results was conducted using the program Statistica, version 13.1 (StatSoft Inc., Washington, DC, USA). The significance of the impact of the tested doses of foliar fertilizer on the dry matter of the aboveground parts of the plant, the dry mass of roots of maize plants and the maize yield obtained was evaluated by the analysis of variance, determining the half-confidence intervals by the NIR test at the significance level $\alpha=0.05$.

\section{Results and Discussion}

\subsection{The Solubilization Procedure of Minerals from Calcined Bones}

A number of research teams have been engaged in developing methods to reclaim phosphorus from different sources. The most basic approach is the solubilization of phosphorus compounds and then selective isolation, e.g., by means of struvite precipitation [21,22]. Phosphorus, in this form, may be utilized as a fertilizer. These technologies provide fertilizers that can be applied directly to soil. However, there is also an important class of fertilizers applied in the form of foliar spraying. In the available literature data, there is no information about utilization of foliar fertilizers that were produced from waste, such as sewage sludge, or from animal production. In particular, the animal waste from slaughterhouses such as animal bones are rich in phosphorus, which can be found in the form of hydroxyapatites, e.g., $\mathrm{Ca}_{10}\left(\mathrm{PO}_{4}\right)_{6}(\mathrm{OH})_{2}$. Besides phosphorus, the main element present in these minerals is calcium. The bones from slaughterhouses are a hazardous waste which needs to be further processed. One of the technologies utilized for the treatment of the bone waste is thermal processing. High temperatures in the range of $850-950{ }^{\circ} \mathrm{C}$ cause its total mineralization. The minerals, after that treatment, become an attractive source of different elements including phosphorus that could be used as fertilizer. The composition of the waste obtained after thermal processing was summarized in Table 1.

It was observed, that the raw material is rich in various elements that can be used by plant organisms. There is over $17 \%$ of phosphorus present as pure $\mathrm{P}$ and a number of other elements such as 
$\mathrm{Ca}, \mathrm{Fe}, \mathrm{Mn}, \mathrm{Zn}$ or $\mathrm{Cu}$. These elements are often found in various fertilizers [23]. However, it remains challenging to transfer these elements in their soluble forms. The utilization of sulfuric acid, for the extraction of phosphorus from hydroxyapatites results in the generation of $\mathrm{CaSO}_{4}$, i.e., the so called phosphogypsum. It is also possible to use hydrochloric acid solution for phosphorus solubilization. However direct fertilization using this solution is impossible due to the high content $\mathrm{Cf}^{-}$ions, which cause soil salinity [12,24]. After screening of acids solution which could be potentially used for the extraction of phosphorus, we found that the amount of reclaimed minerals was satisfactory only in the case of nitric acid. The reaction mixture was prepared as a: $25 \mathrm{~g}$ of bone waste, $120 \mathrm{~g}$ of water, and $42 \mathrm{~g}$ of nitric acid at the concentration of $65 \%$. In fact, it was possible to solubilize $95 \%$ of bone waste material. The solution which contained most of the elements present in bone waste was later concentrated using distillation under reduced pressure. Next, the solution was dried at $60^{\circ} \mathrm{C}$ under a pressure of $0.001 \mathrm{MPa}$ and, as a result, a solid substance in the form of a paste was produced. The composition of the soluble fraction was determined, and the results are summarized in Tables 3 and 4 .

It was shown that $75 \%$ of the elements present in bone waste was transferred into the soluble fraction. The efficiency of the process was determined according to Equation (1):

$$
\mathrm{SF}(\%)=\frac{\left(\mathrm{mSF}-\mathrm{mHNO}_{3}\right) \cdot 100}{\mathrm{mBW}}
$$

where SF refers to the content of the soluble fraction, mSF refers to the mass of soluble fraction (g), $\mathrm{mHNO}_{3}$ refers to the mass of nitric acid $(\mathrm{V})(\mathrm{g})$ and $\mathrm{mBW}$ refers to the mass of bone waste $(\mathrm{g})$.

The rate of the waste recovery is satisfactory taking into account that the waste bone consisted of hydroxyapatite but also carbonates, which, as a result of the reaction with nitric acid, convert to carbon dioxide. Hydroxyapatite during the reaction with nitric acid converts mainly to calcium nitrate and calcium dihydrogen phosphate according to following reaction (2):

$$
\mathrm{Ca}_{10}(\mathrm{OH})_{2}\left(\mathrm{PO}_{4}\right)_{6}+14 \mathrm{HNO}_{3} \rightarrow 7 \mathrm{Ca}\left(\mathrm{NO}_{3}\right)_{2}+3 \mathrm{Ca}\left(\mathrm{H}_{2} \mathrm{PO}_{4}\right)_{2}+2 \mathrm{H}_{2} \mathrm{O}
$$

These compounds are well-known components of various fertilizers. It is obvious that the introduction of microelements and macroelements at a certain stage of plant development results in the improvement in their survivability and growth rate. Most fertilizers include a number of components, such as $\mathrm{Fe}, \mathrm{Mn}, \mathrm{Zn}, \mathrm{Cu}, \mathrm{Mg}$, $\mathrm{Ca}$ or $\mathrm{K}$. These elements were also detected in the obtained product, which is presented in Table 3. The composition of the soluble fraction is presented as a mean value $( \pm \mathrm{SD})$ for not less than three experiments. Moreover, the obtained product is rich in valuable anions such as nitrates and phosphates, which are the source of the phosphorus (Table 3).

\subsection{Pot Experiments}

Foliar fertilizing is a key element of intensive plant production, which enables the supply of nutrients under conditions of difficult uptake from the soil and in phases of great demand $[25,26]$ and is characterized by the high production efficiency of elements introduced in this way [24].

The observed high effectiveness of the tested fertilizer applied at relatively low doses ( $35.4 \mathrm{mg} \mathrm{pot}^{-1}$ ) probably stems from the beneficial proportions of microelements and macroelements, characteristic for living organisms, which were isolated from natural resources of animal origin. As a consequence, foliar application of the tested fertilizer had impact on the production efficacy of plants during the initial stages of development, and thus the plants were more immune to biotic and abiotic stress factors. The utilized doses of the foliar fertilizer during the pot experiments had an impact on the dry mass of both the aboveground underground parts of the maize plant. The mass of these parts of the maize plant increases with an increasing dose of the fertilizer (Table 5). The highest, 19.6\%, increase in the dry mass of the aboveground parts of the maize plant in comparison to the control plants was observed in the case where the fertilizer dose was $35.4 \mathrm{mg} \mathrm{pot}^{-1}\left(3.0 \mathrm{~kg} \mathrm{ha}^{-1}\right)$. The utilization of that 
dose also resulted in a high dry mass of the underground parts of the plants of the maize plant, which amounted to approximately $1.21 \mathrm{~g}$ per plant and was twice as high for plants without foliar fertilizing. An increase in the biomass production determined by the total plant dry mass as a result of fertilization with phosphorus was also observed by other authors [27].

Table 5. Biometric features of the maize plants 14 days after foliar fertilization.

\begin{tabular}{|c|c|c|c|}
\hline \multirow[b]{2}{*}{$\begin{array}{l}\text { Fertilizer Dose } \\
\text { mg pot }^{-1}\end{array}$} & \multicolumn{3}{|c|}{ Biometric Features of Maize Plants } \\
\hline & $\begin{array}{l}\text { Relative Amount of } \\
\text { Chlorophyll (SPAD) }\end{array}$ & $\begin{array}{l}\text { Dry Mass of the Aboveground } \\
\text { Parts of the Plant } \\
\text { g Plant }{ }^{-1}\end{array}$ & $\begin{array}{l}\text { Dry Mass of the Underground } \\
\text { Parts of the Plant } \\
\text { g Plant }^{-1}\end{array}$ \\
\hline 0 & $37.20 \mathrm{a}$ & $12.10 \mathrm{a}$ & $0.63 \mathrm{a}$ \\
\hline 11.8 & $39.30 \mathrm{~b}$ & $12.39 \mathrm{a}$ & $0.86 \mathrm{~b}$ \\
\hline 23.6 & $39.63 c$ & $14.27 \mathrm{~b}$ & $0.93 \mathrm{c}$ \\
\hline 35.4 & $45.20 \mathrm{~d}$ & $14.47 \mathrm{c}$ & $1.21 \mathrm{~d}$ \\
\hline
\end{tabular}

Plant growth is dependent on physiological processes and in particular on the photosynthesis process. The determination of the amount of the chlorophyll within plant leaves is one of the methods which can be utilized for the evaluation of various factors that have an impact on the plant, i.e., the composition of fertilizers applied onto the plant leaves [24]. The conducted measurements of the relative amount of chlorophyll in the maize plant leaves showed the statistically significant differences between the chlorophyll amounts in plants exposed to various doses of the tested fertilizer (Table 5). The flag leaves of the maize plants fertilized with the various doses of the fertilizer had a statistically significant higher amount of chlorophyll in comparison to the plants grown in the control objects. The highest increase in the plant parameters was observed in the plants fertilized with a fertilizer dose of $35.4 \mathrm{mg} \mathrm{pot}^{-1}\left(3.0 \mathrm{~kg} \mathrm{ha}^{-1}\right)$. The relative amount of chlorophyll in the maize plant leaves fertilized with such a dose of the fertilizer increased by $21.5 \%$ in comparison to the plants grown in the control vases.

The foliar application of microelements and macroelements in the tested fertilizer (Table 3) counteracted the deficiencies of nutrients, which were observed on the plants grown in the control vases. Better supply of nutrients to the fertilized plants improved their vigor and resistance to stress factors, which in turn resulted in an increased mass of roots and the aboveground parts of the plant and better physiologic parameters (Tables 5 and 6).

Table 6. Content of selected microelements and macroelements in the aboveground and underground parts of the maize plant 14 days after foliar fertilization.

\begin{tabular}{|c|c|c|c|c|c|c|c|c|c|}
\hline \multirow{2}{*}{$\begin{array}{l}\text { Fertilizer Dose } \\
\quad \mathrm{mg} \mathrm{pot}^{-1}\end{array}$} & $\mathbf{P}$ & $\mathrm{Ca}$ & $\mathbf{K}$ & $\mathrm{Na}$ & Mg & $\mathrm{Fe}$ & Mn & Zn & $\mathrm{Cu}$ \\
\hline & \multicolumn{5}{|c|}{$\mathrm{g} \mathrm{kg}^{-1}$} & \multicolumn{4}{|c|}{$\mathrm{mg} \mathrm{kg}^{-1}$} \\
\hline \multicolumn{10}{|c|}{ Underground Parts of the Plant } \\
\hline 0 & $0.19 \mathrm{a}$ & $1.66 \mathrm{a}$ & $4.53 \mathrm{~b}$ & $0.98 \mathrm{~b}$ & $0.64 \mathrm{a}$ & $167.16 \mathrm{c}$ & $102.54 \mathrm{~d}$ & $25.88 \mathrm{a}$ & $4.40 \mathrm{a}$ \\
\hline 11.8 & $0.22 \mathrm{~b}$ & $2.11 \mathrm{c}$ & $3.97 \mathrm{a}$ & $0.98 \mathrm{~b}$ & $0.71 \mathrm{c}$ & $171.05 \mathrm{~d}$ & $74.01 \mathrm{~b}$ & $39.75 \mathrm{c}$ & $6.61 \mathrm{c}$ \\
\hline 23.6 & $0.28 \mathrm{~d}$ & $1.83 \mathrm{~b}$ & $4.67 \mathrm{c}$ & $0.88 \mathrm{a}$ & $0.66 \mathrm{~b}$ & $171.54 \mathrm{a}$ & $55.87 \mathrm{a}$ & $33.33 \mathrm{~b}$ & $5.86 \mathrm{~b}$ \\
\hline 35.4 & $0.25 \mathrm{c}$ & $2.57 \mathrm{~d}$ & $4.85 \mathrm{~d}$ & $1.28 \mathrm{c}$ & $0.88 \mathrm{~d}$ & $115.84 \mathrm{~b}$ & $81.68 \mathrm{c}$ & $50.67 \mathrm{~d}$ & $7.32 \mathrm{~d}$ \\
\hline \multicolumn{10}{|c|}{ Aboveground Parts of the Plant } \\
\hline \multicolumn{5}{|c|}{$\mathrm{g} \mathrm{kg}^{-1}$} & \multicolumn{5}{|c|}{$\mathrm{mg} \mathrm{kg}^{-1}$} \\
\hline 0 & $3.19 \mathrm{c}$ & $5.53 \mathrm{a}$ & $32.2 \mathrm{a}$ & $0.09 \mathrm{~b}$ & $1.90 \mathrm{a}$ & $245.63 \mathrm{~d}$ & $58.65 \mathrm{~d}$ & $66.78 \mathrm{~b}$ & $10.71 \mathrm{c}$ \\
\hline 11.8 & $4.22 \mathrm{~d}$ & $7.26 \mathrm{c}$ & $37.0 \mathrm{~b}$ & $0.17 \mathrm{~d}$ & $2.39 \mathrm{~b}$ & $198.77 \mathrm{c}$ & $50.40 \mathrm{~b}$ & $59.56 \mathrm{a}$ & $8.36 \mathrm{~b}$ \\
\hline 23.6 & $4.16 \mathrm{a}$ & $10.09 \mathrm{~d}$ & $43.8 \mathrm{~d}$ & $0.06 \mathrm{a}$ & $3.00 \mathrm{~d}$ & $215.14 \mathrm{a}$ & $37.16 \mathrm{a}$ & $71.21 \mathrm{c}$ & $8.29 a$ \\
\hline 35.4 & $3.27 \mathrm{~b}$ & $6.40 \mathrm{~b}$ & $38.9 \mathrm{c}$ & $0.11 c$ & $2.65 c$ & $192.79 \mathrm{~b}$ & $52.69 \mathrm{c}$ & $80.81 \mathrm{~d}$ & $11.76 \mathrm{~d}$ \\
\hline
\end{tabular}

Note. $\mathrm{a}, \mathrm{b}, \mathrm{c}-$ means within rows with different letters differ significantly at $p \leq 0.05$. 


\subsection{Field Experiments}

The results from the field experiments in selected locations (Figure 1, Table 2) confirmed the statistically significant effect of the dose of $3.0 \mathrm{~kg} \mathrm{ha}^{-1}$ of the tested foliar fertilizer on plant growth and the dry mass of aboveground parts of the maize plant and roots of the maize plant on the 14th day after application of foliar fertilization. The plants fertilized with the tested fertilizer were higher than $40.5 \%$ (location C) to $154.8 \%$ (location D) compared to the plants from control objects. The foliar application of the fertilizer caused an increase in the dry biomass of the aboveground parts of plants, which on average was higher by $75.5 \%$ in comparison to the plants that were not fertilized with foliar fertilizer. The dry mass of the underground parts of plants fertilized was higher from plants from control facilities by $81.4 \%$.

In literature there are reports about a several percent increase in crop yields as a result of foliar fertilization, in particular for solutions of poly compound mixtures and micronutrient fertilizers [28-30]. Also, the growth time can be reduced and therefore it is possible to harvest crops earlier [31]. In the field experiments, the applied dose of the tested foliar fertilizer, independent of meteorological conditions as well as the soil conditions, resulted in an increased maize grain yield on average from $4.2 \%$ (location C) to $7.3 \%$ (location B) in comparison to yields obtained without foliar fertilization. The foliar fertilizer tested in the indicated locations resulted in, on average, a 5.1\% increase in the final yield of grain in comparison to the yield of plants without foliar fertilization (Table 7).

Table 7. Biometric features of maize plant 14 days after foliar fertilization and the final mass of the maize crop.

\begin{tabular}{|c|c|c|c|c|c|c|c|c|}
\hline \multirow[t]{3}{*}{ Fertilizer Dose $\mathrm{kg} \mathrm{ha}^{-1}$} & \multicolumn{6}{|c|}{ Biometric Features of Maize Plant } & \multirow{2}{*}{\multicolumn{2}{|c|}{ Maize Graint ha ${ }^{-1}$}} \\
\hline & \multicolumn{2}{|c|}{$\begin{array}{l}\text { Plants Highcm } \\
\text { Plant }^{-1}\end{array}$} & \multicolumn{2}{|c|}{$\begin{array}{l}\text { Dry Mass of the } \\
\text { Aboveground Parts of } \\
\text { the Plantg Plant }{ }^{-1}\end{array}$} & \multicolumn{2}{|c|}{$\begin{array}{l}\text { Dry Mass of the } \\
\text { Underground Parts of } \\
\text { the Plantg Plant }{ }^{-1}\end{array}$} & & \\
\hline & 0 & 3.0 & 0 & 3.0 & 0 & 3.0 & 0 & 3.0 \\
\hline A & $184.0 \mathrm{a}$ & $207.3 \mathrm{~b}$ & $80.1 \mathrm{a}$ & $117.8 \mathrm{~b}$ & $62.3 \mathrm{a}$ & $117.8 \mathrm{~b}$ & $13.4 \mathrm{a}$ & $14.0 \mathrm{~b}$ \\
\hline B & $122.3 \mathrm{a}$ & $211.4 \mathrm{~b}$ & $188.6 \mathrm{a}$ & $479.2 \mathrm{~b}$ & $28.5 \mathrm{a}$ & $39.4 \mathrm{~b}$ & $11.0 \mathrm{a}$ & $11.8 \mathrm{~b}$ \\
\hline $\mathrm{C}$ & 153.0 & 167.3 & $247.0 \mathrm{a}$ & $347.7 \mathrm{~b}$ & $38.4 \mathrm{a}$ & $69.1 \mathrm{~b}$ & $12.0 \mathrm{a}$ & $12.5 \mathrm{~b}$ \\
\hline $\mathrm{D}$ & $121.0 \mathrm{a}$ & $183.7 \mathrm{~b}$ & $83.7 \mathrm{a}$ & $170.2 \mathrm{~b}$ & $29.1 \mathrm{a}$ & $41.9 \mathrm{~b}$ & $11.4 \mathrm{a}$ & $11.9 \mathrm{~b}$ \\
\hline $\mathrm{E}$ & 95.3 & 110.0 & $107.4 \mathrm{a}$ & $161.0 \mathrm{~b}$ & $29.0 \mathrm{a}$ & $54.2 \mathrm{~b}$ & $10.1 \mathrm{a}$ & $10.6 \mathrm{~b}$ \\
\hline $\mathrm{F}$ & $155.5 \mathrm{a}$ & $172.3 \mathrm{~b}$ & $307.2 \mathrm{a}$ & $419.5 \mathrm{~b}$ & $39.9 \mathrm{a}$ & $84.6 \mathrm{~b}$ & $12.2 \mathrm{a}$ & $12.8 \mathrm{~b}$ \\
\hline G & $101.7 \mathrm{a}$ & $196.3 \mathrm{~b}$ & $218.0 \mathrm{a}$ & $376.9 \mathrm{~b}$ & $41.2 \mathrm{a}$ & $57.7 \mathrm{~b}$ & $10.5 \mathrm{a}$ & $11.2 \mathrm{~b}$ \\
\hline $\mathrm{H}$ & 102.3 & 108.7 & $75.1 \mathrm{a}$ & $148.1 \mathrm{~b}$ & $15.2 \mathrm{a}$ & $39.1 \mathrm{~b}$ & $11.6 \mathrm{a}$ & $12.1 \mathrm{~b}$ \\
\hline
\end{tabular}

Note. $\mathrm{a}, \mathrm{b}, \mathrm{c}-$ means within rows with different letters differ significantly at $p \leq 0.05$.

\section{Conclusions}

The utilization of a nitric acid solution for the solubilization of minerals from animal bones provided a solution rich in $\mathrm{N}-\mathrm{NO}_{3}, \mathrm{PO}_{4}{ }^{3-}$ and macro- and microelements of high fertilization value. The isolates have been successfully used as foliar fertilizers in the cultivation of maize plant. The application of a fertilizer dose of $3 \mathrm{~kg} \mathrm{ha}^{-1}$ had a positive impact on both aboveground and belowground parts of maize and the physiological parameters in the initial stage of plant development.

The fertilizer tested in field experiments with boron and molybdenum compounds confirmed the effectiveness of the fertilizing effect in various soil and climatic conditions in maize cultivation by increasing the biometric features of plants in the initial phase of their growth and development, as well as the increase in maize grain production (on average, by $600 \mathrm{~kg} \mathrm{ha}^{-1}$ ). 
Author Contributions: Conceptualization, methodology and writing—original draft, M.B., N.M. and P.A.; Formal analysis, J.G.; Investigation, M.P.; Funding acquisition, G.W.; Investigation and writing-original draft, M.S.

Funding: The research was conducted as part of the project entitled "Development of innovative fertilizers on the basis of an alternative source of raw material" No. BIOSTRATEG1/270963/6/NCBR/2015 co-financed by public funds, at the disposal of the National Center for Research and Development under the "NATURAL ENVIRONMENT, AGRICULTURE AND FORESTRY" Program-BIOSTRATEG. The Article Processing Charge was covered with the project founds.

Conflicts of Interest: The authors declare no conflict of interest.

\section{References}

1. Dawson, C.J.; Hilton, J. Fertilizer availability in a resource limited world: Production and recycling of nitrogen and phosphorus. Food Policy 2011, 36, 14-22. [CrossRef]

2. Gorazda, K.; Tarko, B.; Wzorek, Z.; Kominko, H.; Nowak, A.K.; Kulczycka, J.; Henclik, A.; Smol, M. Fertilizers production from ashes after sewage sludge combustion-A strategy towards sustainable development. Environ. Res. 2017, 154, 171-180. [CrossRef] [PubMed]

3. De Ridder, M.; De Jong, S.; Polchar, J.; Lingemann, S. Risks and Opportunities in the Global Phosphate Rock Market; The Hague Centre for Strategic Studies (HCSS): Hague, The Netherlands, 2012.

4. Rittmann, B.E.; Mayer, B.; Westerhoff, P.; Edwards, M. Capturing the lost phosphorus. Chemosphere 2011, 84, 846-853. [CrossRef] [PubMed]

5. Jastrzębska, M.; Saeid, A.; Kostrzewska, M.K.; Baśladyńska, S. New phosphorus biofertilizers from renewable raw materials in the aspect of cadmium and lead contents in soil and plants, P-biofertilizers from waste and $\mathrm{Cd}$ and $\mathrm{Pb}$ in soil and plant. Open Chem. 2018, 16. [CrossRef]

6. Rolewicz, M.; Rusek, P.; Borowik, K. Obtaining of granular fertilizers based on ashes from combustion of waste residues and ground bones using phosphorus solubilization by bacteria Bacillus megaterium. J. Environ. Manag. 2017, 216, 128-132. [CrossRef] [PubMed]

7. Ehmann, A.; Bach, I.-M.; Laopeamthong, S.; Bilbao, J.; Lewandowski, I. Can phosphate salts recovered from manure replace conventional phosphate fertilizer? Agriculture 2017, 7, 1. [CrossRef]

8. Smith, M.T.E.; Cade-Menun, B.J.; Tibbett, M. Soil phosphorus dynamics and phytoavailability from sewage sludge at different stages in a treatment stream. Biol. Fertil. Soils 2006, 42, 186-197. [CrossRef]

9. Staroń, A.; Kowalski, Z.; Banach, M.; Wzorek, Z. Methods of thermal utilization of animal waste. Chem. Czas. Tech. Chem. Tech. Trans. 2010, 107, 323-332.

10. Saeid, A.; Labuda, M.; Chojnacka, K.; Górecki, H. Valorization of Bones to Liquid Phosphorus Fertilizer by Microbial Solubilization. Waste Biomass Valor. 2014, 5, 265-272. [CrossRef]

11. Bovine Spongiform Encephalopathy (BSE), World Health Organization. Available online: https://www.who. int/zoonoses/diseases/bse/en/ (accessed on 3 September 2019).

12. Demirbas, A.; Abal1, Y.; Mert, E. Recovery of phosphate from calcined bone by dissolution in hydrochloric acid solutions. Res. Conserv. Rec. 1999, 26, 251-258. [CrossRef]

13. Xiao, C.-Q.; Chi, R.-A.; Huang, X.-H.; Zhang, W.-X.; Qiu, G.-Z.; Wang, D.-Z. Optimization for rock phosphate solubilization by phosphate-solubilizing fungi isolated from phosphate. Ecol. Eng. 2008, 33, 187-193. [CrossRef]

14. Vassileva, M.; Azcon, R.; Barea, J.-M.; Vassilev, N. Rock phosphate solubilization by free and encapsulated cells of Yarowia lipolytica. Process Biochem. 2000, 35, 693-697. [CrossRef]

15. Vassilev, N.; Vassileva, M.; Fenice, M.; Federici, F. Immobilized cell technology applied in solubilization of insoluble inorganic (rock) phosphates and P plant acquisition. Bioresour. Technol. 2001, 79, 263-271. [CrossRef]

16. Fazy rozwojowe podstawowych zbóż w skali BBCH z komentarzem agrotechnicznym. Wiadomości Rol. Pol. 2018, 151.

17. Coste, S.; Baraloto, C.; Leroy, C.; Marcon, É.; Renaud, A.; Richardson, A.D.; Roggy, J.-C.; Schimann, H.; Uddling, J.; Hérault, B. Assessing foliar chlorophyll contents with the SPAD-502 chlorophyll meter: A calibration test with thirteen tree species of tropical rainforest in French Guiana. Ann. For. Sci. 2010, 67, 607. [CrossRef]

18. Kukurydza-Informacje Ogólne, Instytut Hodowli i Aklimatyzacji Roślin-Państwowy Instytut Badawczy. Available online: http://www.zdhar.pl/kukurydza.htm (accessed on 5 August 2019). 
19. Weather, Institute of Meteorology and Water Management. Available online: http://www.imgw.pl/en/ (accessed on 5 August 2019).

20. Ostrowska, A.; Gawliński, S.; Szczubiałka, Z. Methods of Analysis and Assessment of Soil and Plant Properties; Environmental Protection Institute: Warszawa, Poland, 1991.

21. Kruk, D.J.; Elektorowicz, M.; Oleszkiewicz, J.A. Struvite precipitation and phosphorus removal using magnesium sacrificial anode. Chemosphere 2014, 101, 28-33. [CrossRef] [PubMed]

22. Wzorek, Z. Alternative phosphorus raw materials. Przemyst Chem. 2006, 85, 880-882.

23. Witek, G.; Gorzelany, J.; Matłok, N. The impact of Dr Green foliar fertilization on plant health during the growing period as well as on the potato yield and quality (Jelly variety). Agric. Eng. 2016, 20, 151-158. [CrossRef]

24. Jaskulski, D. Comparsion of the effect of foliar fertilization fertilizers on economic and production effects of growing some field crops. Fragm. Agron. 2007, 1, 106-112.

25. Michałojć, Z.; Szewczuk, C. Theoretical aspects of foliar nutrition of plants. Acta Agrophys. 2003, 85, 7-28.

26. Sienkiewicz-Cholewa, U. The importance of microelements in rape fertilization. Zesz. Post. Nauk Rol. 2002, 5, 19-28.

27. Bukvić, G.; Antunović, M.; Popović, S.; Rastija, M. Effect of P and Zn fertilisation on biomass yield and its uptake by maize lines (Zea mays L.) Plant. Soil Environ. 2003, 49, 505-510. Plant. Soil Environ. 2003, 49, 505-510.

28. Barczak, B.; Nowak, K.; Kozera, W.; Majcherczak, E. The effect of foliar fertilization with microelements on the size of spring barley grain yield. Fragm. Agron. 2005, 4, 5-18.

29. Jaskulski, D.; Jaskulska, I. Production effect of foliar application of magnesium and microelements fertilizer Sonata on the cultivation of winter wheat depending on the rainfall and soil richness. Zesz. Probl. Post. Nauk. Rol. 2009, 541, 157-164.

30. Kulczycki, G.; Januszkiewicz, R.; Jachymczak, A. The effect of foliar applied fertilizer ekolist on the yield and chemical composition of spring wheat. Zesz. Nauk. UP Wrocław. 2009, 574, 19-28. (In Polish)

31. Abdel-Aziz, H.M.M.; Hasaneen, M.N.A.; Omer, A.M. Nano chitosan-NPK fertilizer enhances the growth and productivity of wheat plants grown in sandy soil. Span. J. Agric. Res. 2016, 14. [CrossRef]

(C) 2019 by the authors. Licensee MDPI, Basel, Switzerland. This article is an open access article distributed under the terms and conditions of the Creative Commons Attribution (CC BY) license (http://creativecommons.org/licenses/by/4.0/). 